\title{
CO-INFESTATION OF GILLS BY DIFFERENT PARASITE GROUPS IN THE MULLET, Mugil platanus GÜNTHER, 1880 (OSTEICHTHYES, MUGILIDAE): EFFECTS ON RELATIVE CONDITION FACTOR
}

\author{
RANZANI-PAIVA, M. J. T. ${ }^{1}$ and SILVA-SOUZA, A. T. ${ }^{2}$ \\ ${ }^{1}$ Instituto de Pesca, Av. Francisco Matarazzo, 455, CEP 05001-900, São Paulo, SP, Brazil \\ ${ }^{2}$ Departamento de Biologia Animal e Vegetal, Centro de Ciências Biológicas, Universidade Estadual de Londrina, \\ C.P. 6001, CEP 86051-990, Londrina, PR, Brazil \\ Correspondence to: Ângela Teresa Silva-Souza, Departamento de Biologia Animal e Vegetal, CCB, Universidade \\ Estadual de Londrina, C.P. 6001, CEP 86051-990, Londrina, PR, Brazil, e-mail: ateresa@uel.br
}

Received December 10, 2002 - Accepted March 13, 2003 - Distributed August 31, 2004

(With 2 figures)

\begin{abstract}
This study involved 334 specimens of mullet, Mugil platanus, captured monthly in the estuarine region of Cananéia, São Paulo State, Brazil, from July 1988 to June 1989, and examined for the presence of gill parasites. Parasitological inspections revealed the occurrence of the following groups: Trichodina sp., Monogenoidea, Copepoda, and Hirudinea. Only four mullets were not parasitized. Total weight and total length of all 334 mullet specimens examined were used for adjusting the weight-length relationship curve and calculating the relative condition factor $(\mathrm{Kn})$. The 118 specimens infested with monogenoideans on average had lower weights than expected $(\mathrm{Kn}<1.0)$, and the 81 fish co-infested with Copepoda, Monogenoidea, and Trichodina sp. showed a $\mathrm{Kn}<1.0$. The other infested and noninfested mullets had a $\mathrm{Kn}>1$.0. It was possible to infer that gill infestation with monogenoideans alters mullet weight, especially in the presence of co-infestation with Trichodina sp. and copepods.
\end{abstract}

Key words: relative condition factor, Mugil platanus, co-infestation, parasitism.

\section{RESUMO}

\section{Co-infestação das brânquias de tainha, Mugil platanus Günther, 1880 (Osteichthyes, Mugilidae), por diferentes grupos de parasitos: efeitos no fator de condição relativo}

Foram examinados exemplares de tainha, Mugil platanus, capturados mensalmente na região estuarinolagunar de Cananéia, SP, entre julho de 1988 e junho de 1989, a fim de verificar a ocorrência de parasitos branquiais. Das 334 tainhas examinadas, apenas quatro não apresentaram nenhum parasito. Nas demais, foram encontrados os seguintes grupos: Trichodina sp., Monogenoidea, Copepoda e Hirudinea. Utilizando os valores de peso total (Wt) e de comprimento total (Lt) de todos os espécimes estudados calculou-se o fator de condição relativo (Kn). Constatou-se que os 118 espécimes infestados por monogenóideos encontravam-se, em média, com peso inferior ao esperado. Os 81 espécimes que tinham, concomitantemente nas brânquias, Trichodina sp., copépodos e monogenóideos apresentaram, em média, peso inferior ao esperado. Os demais espécimes parasitados, assim como os não parasitados, estavam com o peso igual ou acima do esperado. Foi possível constatar que o parasitismo das brânquias por monogenóideos afeta o peso das tainhas, Mugil platanus, da região estuarino-lagunar de Cananéia, SP, especialmente quando co-infestado com Trichodina sp. e copépodos.

Palavras-chave: fator de condição relativo, Mugil platanus, co-infestação, parasitismo. 


\section{INTRODUCTION}

Specimens of mullet, Mugil platanus, from Cananéia, São Paulo State, Brazil, have been previously studied by Ranzani-Paiva \& Ishikawa (1996) and Ranzani-Paiva et al. (1997). Using the allometric condition factor $(\mathrm{K})$ these authors did not detect any effect of parasitism on state of mullet health. Significant differences were found only when a statistical comparison was made of specimens maintained under different salinity conditions.

The allometric condition factor $(\mathrm{K})$ is totally dependent on both the length and weight of the fish, and is influenced by factors such as gonad maturation, feeding, and amount of fat (Verani et al., 1997).

The relative condition factor $(\mathrm{Kn})$, first defined by Le Cren (1951) and used initially by Eckmann (1984) to select females of Brycon cf. erythropterus induced to spawn by hypophysation, corresponds to the ratio between observed and theoretically expected weight for a given length. It allows statistical comparison between the estimated value of $\mathrm{Kn}$ and the central value $\mathrm{Kn}=1.0$ (Anderson \& Gutreuter, 1983; Verani et al., 1997; Andrade-Talmelli et al., 2001; Romagosa et al., 2001).

Ranzani-Paiva et al. (2001), using the Kn to compare individuals of Salminus maxillosus from the Mogi-Guaçu River, São Paulo State, showed that, in general, females presented better physical conditions than males.

This index has also been chosen to determine the effect of parasites on their host in natural populations and was so used by Silva-Souza (1998) and Warpechowski (2002) in fish from the Tibagi River, Paraná State, and by Ranzani-Paiva et al. (2000) and Tanaka (2000) in fish from the Paraná River, Paraná State, Brazil. The Kn was also used by Tavares-Dias et al. $(1999,2000)$ to evaluate the state of health of fish in captivity.

The aim of this study was to determine, using the Kn, the effect of co-infestation by Monogenoidea, Copepoda, Trichodina sp., and Hirudinea on mullet health.

\section{MATERIAL AND METHODS}

A total of 334 specimens of the mullet, Mugil platanus Günther, 1880, collected monthly from July 1988 to June 1989 in the estuarine region of Cananéia, São Paulo State, Brazil (Lat. 2500'S - Long. $47^{\circ} 55^{\prime} \mathrm{W}$ ) were examined. Individuals larger than $30 \mathrm{~cm}$ in total length were captured in fixed fencetraps, and those smaller than $30 \mathrm{~cm}$ were collected with throw nets in coastal ponds located on Ilha Comprida and Ilha do Cardoso islands, where the salinity is lower than it is in the estuary.

Fish were transported to the laboratory of the Oceanographic Institute of the University of São Paulo in Cananéia, where they were maintained in 1000-liter asbestos-reinforced concrete tanks until parasite collection. The water in the tanks was continuously aerated using a compressor.

Each fish was weighed (Wt - total weight in grams), measured ( $\mathrm{Lt}$ - total length in centimeters), and then decapitated. Gill scrapings were inspected under a light microscope to detect protozoans. The entire gills were removed and examined under a stereomicroscope for the presence of metazoan parasites along each gill arch separating the lamellae.

Total weight and total length values of all 334 mullet specimens examined were used to adjust the weight-length relationship curve. The $\mathrm{a}$ and $\mathrm{b}$ values, 0.012 and 2.893 respectively, were used to calculate the theoretically expected weight $(\mathrm{We})$ and, then, the relative condition factor $(\mathrm{Kn}=\mathrm{Wt} /$ $\mathrm{We}$ ). The mean $\mathrm{Kn}$ values of each fish group infested with different parasites and of the nonparasitized group were compared to the standard $\mathrm{Kn}=1.0$ by Student's t test. Statistical comparison $(p<0.05)$ of total length and total weight means among the different parasitized groups and between each one and the control group was performed with Tukey's test $(\mathrm{p}<0.05)$.

\section{RESULTS}

The total length of 334 mullets (Mugil platanus) varied between 11.4 and $67.8 \mathrm{~cm}$ and the weight was between 15.0 and 2,800 g. Four mullets were not parasitized and the others showed the following groups of parasites: Trichodina sp., Monogenoidea, Copepoda, and Hirudinea. When the occurrence of each particular parasite group was considered independently of that of the others, the 118 specimens infested with monogenoideans had, on average, weights lower than expected $(\mathrm{Kn}<1.0)$. Mean $\mathrm{Kn}$ values of all mullets with gills not parasitized by monogenoideans were equal to $(\mathrm{Kn}=1.0)$ or higher than that expected $(\mathrm{Kn}>1.0)$ (Table 1).

Examination of the mullets with gills infested by different parasite groups showed that the 81 fish 
co-infested with copepods, monogenoideans, and Trichodina sp. had a Kn $<1.0$ (Table 2). The other parasitized specimens and those not parasitized had weights equal to or greater than that theoretically expected. Similar results were obtained when comparing total length and total weight among the different groups. Mullets co-infested with copepods, monogenoideans, and Trichodina sp. were statistically smaller and leaner than the others $(\mathrm{p}<0.05)$.
The lack of a statistically significant difference from the standard value of 1.0 for the mean $\mathrm{Kn}$ of fish infested with only monogenoideans (2), co-infested with monogenoideans and copepods (8), or co-infested with monogenoideans and Trichodina sp. (13), may have been due to the small number of specimens studied. However, there is a tendency for the $\mathrm{Kn}$ values of these animals to be lower than 1.0 (Figs. 1 and 2).

TABLE 1

Mean values, variation range (Ax), and standard error of the mean (SEM) for the relative condition factor (Kn) of mullets, Mugil platanus, from the estuarine region of Cananéia, São Paulo State, Brazil, with non-parasitized gills or gills infested by each particular parasite group independently of the others present $(p=$ probability level).

\begin{tabular}{|c|c|c|c|c|c|c|c|}
\hline Parasitism & $\mathbf{n}$ & Kn & SEM & \multicolumn{2}{|c|}{$\mathbf{A x}$} & $\mathbf{p}$ & Interpretation \\
\hline Not parasitized & 4 & 0.96 & 0.03 & 0.89 & 1.02 & 0.27 & $\mathrm{Kn}=1.0$ \\
\hline Without trichodinids & 21 & 0.96 & 0.02 & 0.69 & 1.19 & 0.10 & $\mathrm{Kn}=1.0$ \\
\hline With trichodinids & 309 & 1.01 & 0.01 & 0.32 & 1.91 & 0.13 & $\mathrm{Kn}=1.0$ \\
\hline Without copepods & 64 & 1.00 & 0.02 & 0.75 & 1.32 & 0.88 & $\mathrm{Kn}=1.0$ \\
\hline With copepods & 266 & 1.01 & 0.01 & 0.32 & 1.91 & 0.18 & $\mathrm{Kn}=1.0$ \\
\hline Without hirudineans & 280 & 1.00 & 0.01 & 0.32 & 1.91 & 0.91 & $\mathrm{Kn}=1.0$ \\
\hline With hirudineans & 50 & 1.06 & 0.03 & 0.45 & 1.68 & $0.03 *$ & $\mathrm{Kn}>1.0$ \\
\hline Without monogenoideans & 212 & 1.03 & 0.01 & 0.32 & 1.91 & $0.006^{*}$ & $\mathrm{Kn}>1.0$ \\
\hline With monogenoideans & 118 & 0.97 & 0.01 & 0.45 & 1.39 & $0.001^{*}$ & $\mathrm{Kn}<1.0$ \\
\hline
\end{tabular}

$\mathrm{n}=$ number of specimens examined.

$* \mathrm{p}<0.05$.

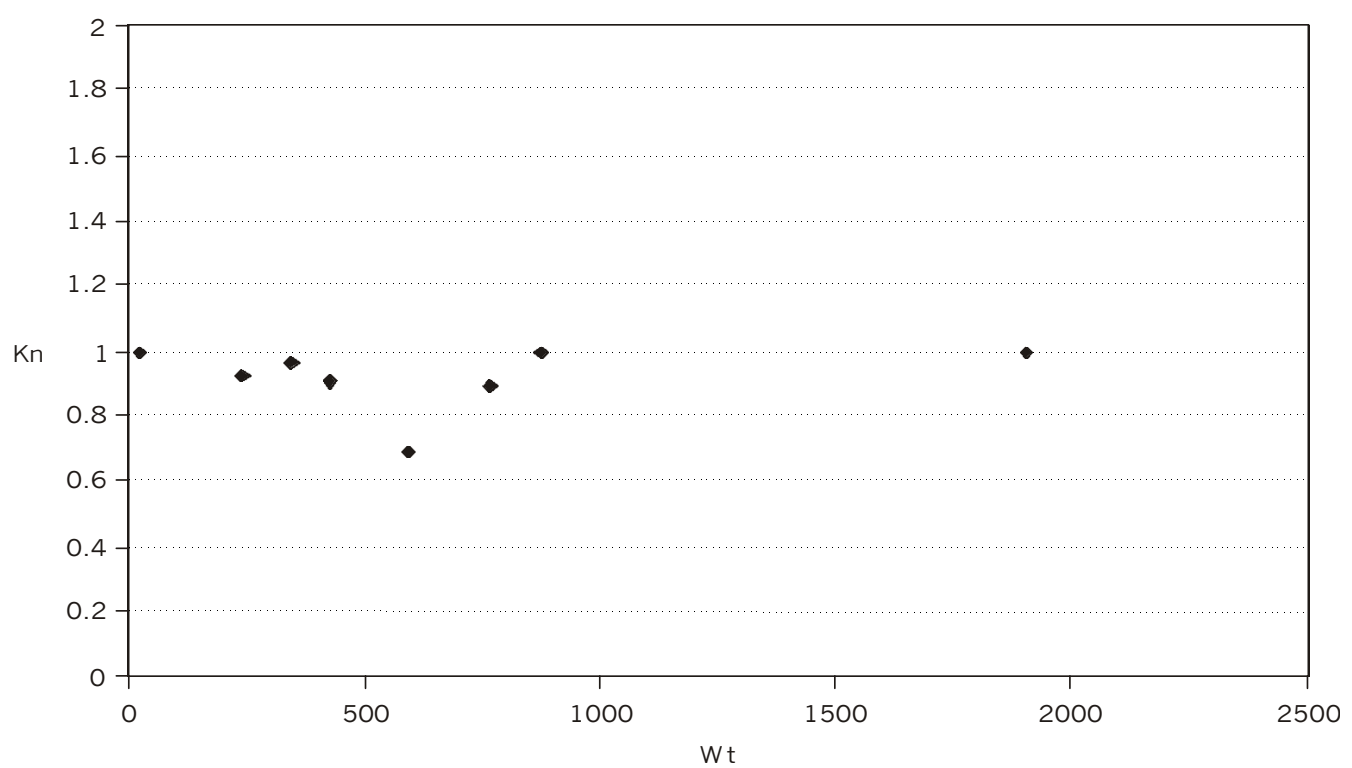

Fig. 1 - Relative condition factor (Kn) of mullets, Mugil platanus, from the estuarine region of Cananéia, São Paulo State, Brazil, with gills co-infested by Trichodina sp. and Monogenoidea. 
TABLE 2

Mean values and standard error of the mean (SEM) for the relative condition factor (Kn), total length (Lt), total weight $(\mathrm{Wt})$, and variation range (Ax) of mullets, Mugil platanus, from the estuarine region of

Cananéia, São Paulo State, Brazil, with non-parasitized gills or gills infested by different parasite groups.

\begin{tabular}{|c|c|c|c|c|c|c|c|c|}
\hline Parasites & n & Kn \pm SEM & \multicolumn{2}{|c|}{ Ax } & $\begin{array}{c}\text { "t” Test. } \\
\text { Ho:Kn = 1.0 }\end{array}$ & Interpretation & Lt \pm SEM & Wt \pm SEM \\
\hline NP & 4 & $0.96 \pm 0.03$ & 0.89 & 1.02 & 0.27 & Kn $=1.0$ & $52.5 \pm 4.0$ & $1168.5 \pm 249.5$ \\
\hline M & 2 & $0.89 \pm 0.15$ & 0.74 & 1.04 & 0.59 & Kn $=1.0$ & $55.9 \pm 3.7$ & $1191.0 \pm 31.0$ \\
\hline C & 10 & $1.01 \pm 0.03$ & 0.91 & 1.19 & 0.82 & Kn $=1.0$ & $35.2 \pm 5.0$ & $519.6 \pm 150.3$ \\
\hline T & 38 & $0.98 \pm 0.13$ & 0.80 & 1.31 & 0.40 & Kn $=1.0$ & $49.1 \pm 1.5$ & $985.6 \pm 60.8$ \\
\hline M-C & 8 & $0.92 \pm 0.04$ & 0.69 & 1.00 & 0.07 & $\mathrm{Kn}=1.0$ & $39.9 \pm 5.1$ & $645.5 \pm 204.8$ \\
\hline M-T & 13 & $0.98 \pm 0.02$ & 0.88 & 1.15 & 0.48 & $\mathrm{Kn}=1.0$ & $47.0 \pm 2.8$ & $897.6 \pm 114.5$ \\
\hline C-T & 129 & $1.04 \pm 0.01$ & 0.52 & 1.90 & $0.02 *$ & $\mathrm{Kn}>1.0$ & $42.5 \pm 1.0$ & $761.4 \pm 43.1$ \\
\hline T-H & 10 & $1.11 \pm 0.05$ & 0.85 & 1.32 & $0.04 *$ & $\mathrm{Kn}>1.0$ & $51.5 \pm 2.1$ & $1239.5 \pm 136.8$ \\
\hline C-H & 1 & 0.91 & 0.91 & 0.91 & - & - & 44.9 & 690.0 \\
\hline C-T-H & 24 & $1.11 \pm 0.04$ & 0.75 & 1.68 & $0.02^{*}$ & $\mathrm{Kn}>1.0$ & $48.7 \pm 1.7$ & $1075.4 \pm 89.6$ \\
\hline M-T-H & 1 & 0.84 & 0.84 & 0.84 & - & - & 61.0 & 2220.0 \\
\hline C-M-T & 81 & $0.97 \pm 0.01$ & 0.76 & 1.39 & $0.01 *$ & $\mathrm{Kn}<1.0$ & $34.7 \pm 1.8$ & $542.2 \pm 68.4$ \\
\hline C-M-T-H & 14 & $1.01 \pm 0.01$ & 0.89 & 1.12 & 0.65 & $\mathrm{Kn}=1.0$ & $47.5 \pm 3.8$ & $1046.0 \pm 187.7$ \\
\hline
\end{tabular}

$\mathrm{NP}=$ not parasitized; $\mathrm{M}=$ Monogenoidea; $\mathrm{C}=$ Copepoda; $\mathrm{T}=$ Trichodina sp.; $\mathrm{H}=$ Hirudinea .

$* \mathrm{p}<0.05$.

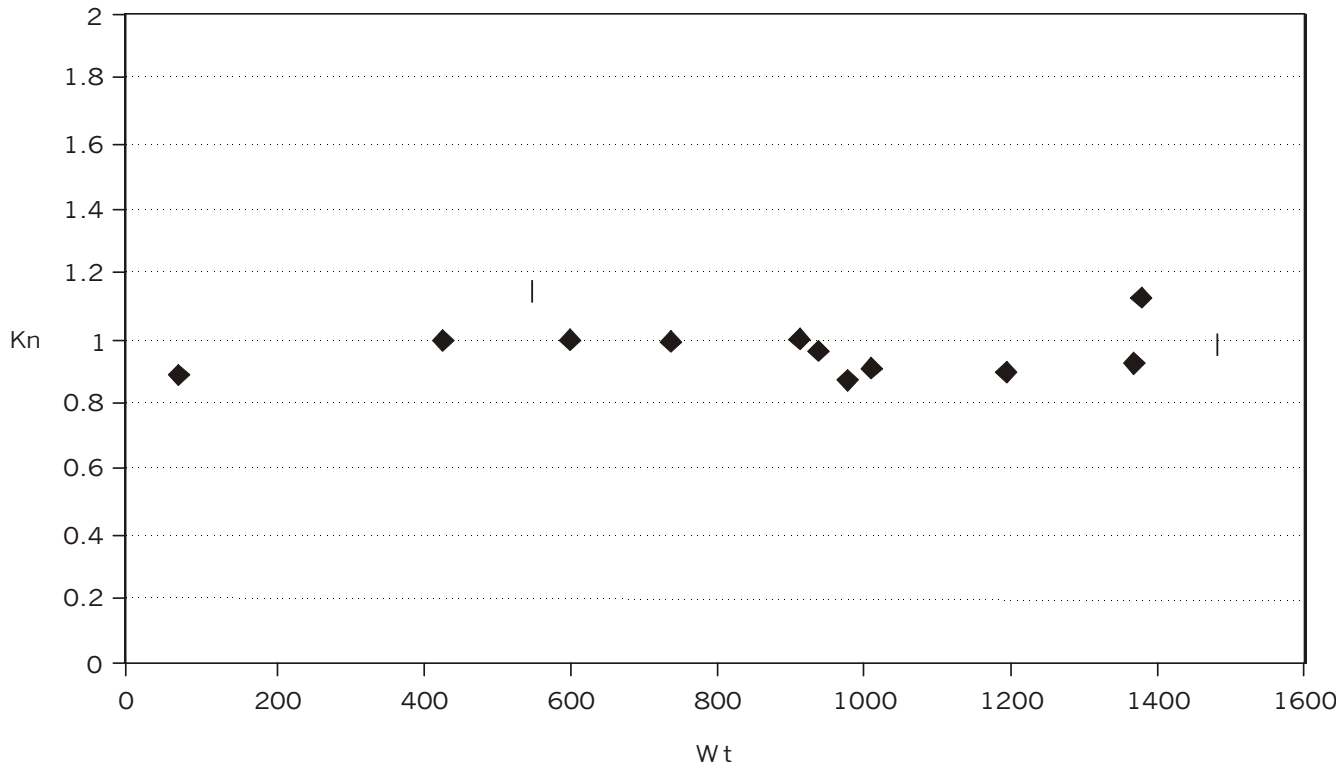

Fig. 2 - Relative condition factor (Kn) of mullets, Mugil platanus, from estuarine region of Cananéia, São Paulo State, Brazil, with gills co-infested by Copepoda and Monogenoidea.

\section{DISCUSSION}

The relative condition factor $(\mathrm{Kn})$ has been used by Silva-Souza (1998) to show that ocular parasitism by Diplostomum (Austrodiplostomum) compactum metacercariae impairs the health of Plagioscion squamosissimus specimens from the Tibagi River. On the other hand, specimens of 
Steindachnerina insculpta from the Tibagi River showed no alteration in weight when found to be suffering from ocular parasitism by Diplostomum sp. metacercariae (Warpechowski, 2002).

Ranzani-Paiva et al. (2000) studied the relative condition factor of Schizodon borellii and Prochilodus lineatus from the Paraná River, and showed that specimens co-infested with Cucullanus pinnai in the intestine and Dactylogyridae in the gills have a total weight close to that expected.

Tanaka (2000) did not find any correlation between parasitism and the relative condition factor in Serrasalmus spilopleura and S. marginatus from the Paraná River.

Mugil platanus from the lagoon-estuarine region of Cananéia seems to be affected by monogenoidean gill parasitism. On the other hand, co-infestation with copepods, Trichodina sp., and Hirudinea does not seem to cause damage to these fish, whose weight was higher than expected.

According to Thatcher \& Boeger (1983) and Thatcher (1991), copepods cause epithelial hyperplasia, metaplasia, and lamellar fusion in the gill filaments of their hosts. This thereby reduces blood circulation in the filaments and causes necrosis. Copepod effect on weight and condition factor of hosts has been observed in several fish species, mainly in cases of high infestation intensity (Eiras, 1994). Copepods found in mullet gills, however, do not seem to alter the condition of these fish, unless they are co-infested with monogenoideans.

Trichodinidae species of marine fishes often infect the gills, while those of freshwater fishes parasitize the skin. Trichodina spp. are essentially ectocommensals feeding on waterborne particles and bacteria as well as detritus particles from the fish surface. Trichodina spp. never occur in large numbers on a healthy fish. When occurring in small numbers, the irritation caused by attachment of their adhesive disc is negligible. Under stressful conditions, trichodinids can proliferate extensively, causing damage to epithelial or epidermal cells, and behaving like dangerous ectoparasites as they feed on injured cells and associated bacterial growth (Lom \& Dyková, 1992).

The direct impact of hirudinean infestations on fish seems to be negligible; however, ulceration, loss of blood ingested by the parasite, and hemorrhage can occur. The most important consequence of this infestation is probably the transmission of other parasites such as Trypanosoma spp. and Cryptobia spp. (Eiras, 1994). Mullet health in Cananéia was not affected by hirudinean parasitism. This was also verified by Ranzani-Paiva et al. (1997) based on hematological parameters.

The pathogenicity of monogenoideans varies according to species, infestation intensity, and attachment site. Monogenoideans on gill filaments may cause cell hyperplasia and excessive mucous production, reducing breathing capacity of the fish. According to Faisal \& Iman (1990), monogenoidean parasitism can decrease the fish Kn because of the hemophagic nature of some species. This was evidenced by results with Mugil platanus in the present work. As demonstrated in Table 1, specimens with monogenoideans had a Kn lower than 1.0, whereas fish not infested by these parasites had $\mathrm{Kn}>1.0$.

Parasite infestation damage is not easily found in natural or in culture populations. Leporinus macrocephalus and Piaractus mesopotamicus maintained in captivity and co-infested with monogenoideans, Trichodina sp., Lernaea cyprinacea, Ichthyophthirius multifiliis, and Piscinoodinium pillulare showed mean total weight values close to that theoretically expected $(\mathrm{Kn}=1.0)$ (Tavares-Dias et al., 1999). Similar results were found by Ranzani-Paiva et al. (2000) for Schizodon borellii and Prochilodus lineatus, from the Paraná River, parasitized with monogenoideans, nematodes, and ergasilids.

To conclude, in the estuarine region of Cananéia monogenoideans harm the normal development of Mugil platanus specimens. This occurs especially when there is co-infestation with copepods and Trichodina sp., which leads to decreased total weight of the animals. In nature, this parasitic effect could be negligible. However, for mullets in captivity coparasitism could lead to an appreciable economic loss.

\section{REFERENCES}

ANDERSON, R. O. \& GUTREUTER, S. J., 1983, Length, weight and associated structural indices. In: L. A. Nielsen, D. L. Johnson (ed.), Fisheries techniques. American Fisheries Society, Maryland, 468p.

ANDRADE-TALMELLI, E. F. de, KAVAMOTO, E. T., ROMAGOSA, E. \& FENERICH-VERANI, N., 2001, Embryonic and larval development of the "piabanha", Brycon insignis Steindachner, 1876 (Pisces, Characidae). Boletim do Instituto de Pesca, 27(1): 21-27.

ECKMANN, R., 1984, Induced reproduction in Brycon cf. erythropterus. Aquaculture, 38: 379-382.

EIRAS, J. C., 1994, Elementos de ictioparasitologia. Fundação Eng. António de Almeida, Porto, Portugal, 339p. 
FAISAL, M. \& IMAN, E.A., 1990, Microcotyle chrysophrii (Monogenea: Polyopisthocotylea), a pathogen for culture and wild sea bream, Sparus auratus, pp. 283-290. In: F. Perkins \& C. Cheung (eds.), Pathology in marine science. Academic Press, New York.

LE CREN, E. D., 1951, The length-weight relationship and seasonal cycle in gonadal weight condition in the perch Perca fluviatilis. J. An. Ecol., 20(2): 201-219.

LOM, J. \& DYKOVÁ, I., 1992, Protozoan parasites of fishes. Elsiever, Amsterdam, London, New York, Tokyo, 309p.

RANZANI-PAIVA, M. J. T. \& ISHIKAWA, C. M., 1996, Haematological characteristics of freshwater-reared and wild mullet, Mugil platanus Günther (Osteichthyes, Mugilidae). Revta. Bras. Zool., 13(3): 561-568.

RANZANI-PAIVA, M. J. T., ISHIKAWA, C. M., CAMPOS, B. E. S. \& EIRAS, A. C., 1997, Haematological characteristics associated with parasitism in mullets, Mugil platanus Günther, from the estuarine region of Cananéia, São Paulo, Brazil. Revta. Bras. Zool., 14(2): 329-339.

RANZANI-PAIVA, M. J. T., SILVA-SOUZA, A. T., PAVANELLI, G. C. \& TAKEMOTO, R. M., 2000, Hematological characteristics and relative condition factor $(\mathrm{Kn})$ associated with parasitism in Schizodon borelli (Osteichthyes, Anostomidae) and Prochilodus lineatus (Osteichthyes, Prochilodontidae) from Paraná River, Paraná, Brazil. Acta Scientiarum, 22(2): 515-521.

RANZANI-PAIVA, M. J. T., RODRIGUES, E. L., VEIGA, M. L. \& EIRAS, A. C., 2001, Association between the hematological characteristics and the biology of the "dourado" Salminus maxillosus Valenciennes, 1840, from Mogi-Guaçu River. Acta Scientiarum, 23(2): 527-533.

ROMAGOSA, E., NARAHARA, M. Y., BORELLA, M. I. \& FENERICH-VERANI, N., 2001, Seleção de fêmeas de matrinxã, Brycon cephalus, induzidas à reprodução. B. Inst. Pesca, 27(2): 139-147.

SILVA-SOUZA, A. T., 1998, Estudo do parasitismo de Plagioscion squamosissimus (Heckel, 1840) (Perciformes, Scianidae) por Diplostomum (Austrodiplostomum) compactum (Lutz, 1928) (Trematoda, Digenea) no rio Tibagi, $P R$. Doctoral Thesis, Universidade Federal de São Carlos, São Carlos, 125p.
TANAKA, L. K., 2000, Aspectos ecológicos dos parasitos de Serrasalmus marginatus Valenciennes, 1847 e Serrasalmus spilopleura Kner, 1860 (Characiformes, Serrasalmidae) do rio Baía, planície de inundação do alto rio Paraná, MS Dissertação de Mestrado em Ciências Ambientais, Universidade Estadual de Maringá, Maringá, PR, 31p.

TAVARES-DIAS, M., FRASCÁ-SCORVO, C. M. D., NOVATO, P. F. C. \& MORAES, F. R., 2000, Hematological characteristics of hybrid Florida red tilapia, Oreochriomis urolopis hornorum x $O$. mossambicus under intensive rearing. In: Proceeding of the 5th International Symposium on Tilapia Aquaculture, RJ, 3 a 7/12. Anais... pp. 533-541.

TAVARES-DIAS, M., SCHALCH, S. H. C., MARTINS, M. L., SILVA, E. D., MORAES, F. R. \& PERECIN, D., 1999, Hematologia de teleósteos brasileiros com infecção parasitária. I. Variáveis do Leporinus macrocephalus Garavelo e Britski, 1988 (Anostomidae) e Piaractus mesopotamicus Holmberg, 1887 (Characidae). Acta Scientiarum, 21(2): 337-342

THATCHER, V., 1991, Amazon fish parasites. Amazoniana, 11(3/ 4): 263-571.

THATCHER, V. \& BOEGER, W. A., 1983, Patologia de peixes da Amazônia brasileira. 3. Alterações histopatológicas em brânquias, provocadas por Ergasilus, Brasergasilus e Acusicola (Crustacea: Cyclopoida: Ergasilidae). Acta Amazônica, 13(2): 441-451.

VERANI, J. R., SATO, Y., FENERICH-VERANI, N. \& VIEIRA, L. J. S., 1997, Avaliação de fêmeas de espécies ícticas aptas à indução reprodutiva: critério embasado no fator de condição relativo. In: Seminário Regional de Ecologia, 8, São Carlos. Anais... UFSCar, São Carlos, pp. 323-332.

WARPECHOWSKI, R., 2002, Estudo do parasitismo ocular de Steindachnerina insculpta (Fernandes-Yepez, 1948) (Osteichthyes, Curimatidae) por metacercárias de Diplostomum cf. alarioides Dubois, 1937, do rio Tibagi, Sertanópolis, PR. Dissertação de Mestrado em Zootecnia, Universidade Federal de Santa Maria, Santa Maria, RS, 48p. 